\title{
Analysis And Testing Of Two Wheeler Suspension Helical Compression Spring
}

\author{
C.Madan Mohan Reddy ${ }^{1}$ D.Ravindra Naik ${ }^{2}$ Dr M.Lakshmi Kantha Reddy ${ }^{3}$ \\ ${ }^{1}$ asst. professor, dept. of ME, Mother Theresa institute of engineering and technology, palamaner. \\ ${ }^{2}$ assosiate professor \& HOD, dept. of ME, Mother Theresa institute of engineering and technology, palamaner. \\ ${ }^{3}$ principal, Mother Theresa institute of engineering and technology, palamaner.
}

\begin{abstract}
Absrtact: - The present work is carried out on modeling, analysis and testing of suspension spring is to replace the existed steel helical spring used in popular two wheeler vehicle. The stress and deflections of the helical spring is going to be reduced by using the new material. The comparative study is carried out between existed spring and new material spring. Static analysis determines the stress and deflections of the helical compression spring in finite element analysis. The testing proto type is used to test the spring under different loading conditions. Finite element analysis methods (FEA) are the methods of finding approximate solutions to a physical problem defined in a finite region or domain. FEA is a mathematical tool for solving engineering problems. In this the finite element analysis values are compared to the experimental values. A typical two wheeler suspension spring is chosen for study. The modeling of spring is developed on pro/E 5.0 analysis is carried out on ansys 14.
\end{abstract}

Keywords: - helical compression spring, stress, deflection, analysis, proe-5, ansys 14.

\section{INTRODUCTION}

A spring is defined as an elastic body, whose function is to distort when loaded and to recover its original shape when the load is removed.

It is an elastic object used to store mechanical energy. Springs are usually made out of spring steel. Small springs can be wound from pre-hardened stock, while larger ones are made from annealed steel and hardened after fabrication.

Some non-ferrous metals are also used including phosphor bronze and titanium for parts requiring corrosion resistance and beryllium copper for springs carrying electrical current (because of its low electrical resistance). When a spring is compressed or stretched, the force it exerts is proportional to its change in length.

Types of springs

Though there are many types of sprigs, these are the main springs which we can see often.

1. Helical springs.

2. Conical and volute springs.

3. Torsion springs.

4. Laminated or leaf springs.

5. Disc or Belleville springs.

\section{Helical springs}

The helical springs are made up of a wire coiled in the form of a helix and are primarily intended for compressive or tensile loads. The cross-section of the wire from which the spring is made be circular, square or rectangular.
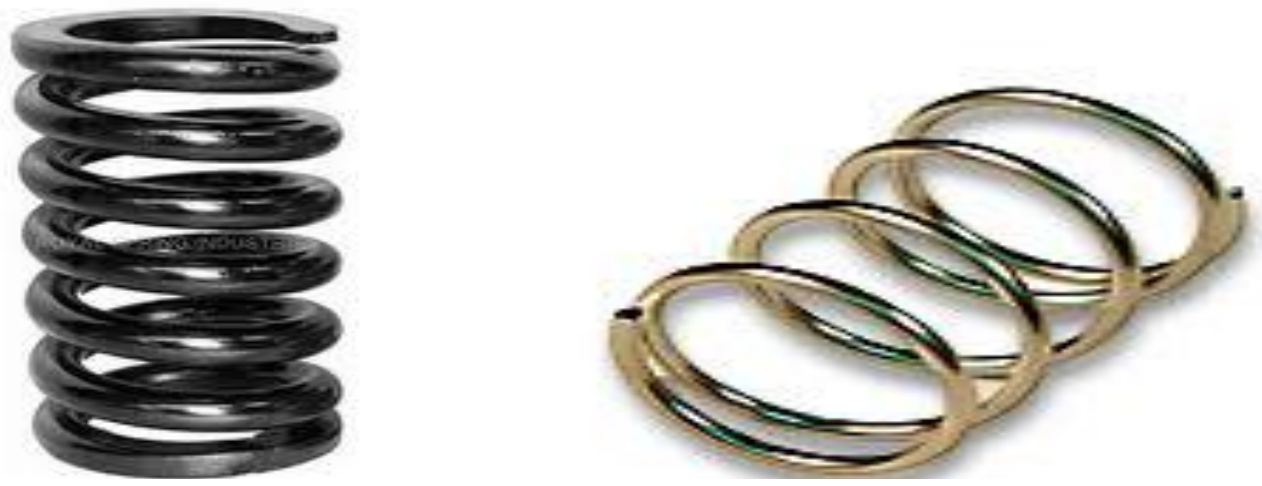

Helical springs. 
The helical springs are said to be closely coiled when the spring wire is coiled so close that the plane containing each turn is nearly at right angles to the axis of the helix and the wire is subjected to torsion. In other words, in a closely coiled helical spring, the helix angle is very small, it is usually less than 10 degree. The major stresses produced in helical springs are shear stresses due to twisting. The load applied is parallel to or along the axis of the spring. In open coiled helical springs, the spring wire is coiled in such a way that there is a gap between the two consecutive turns, as a result of which the helix angle is large.

Helical springs are generally used in two different applications. The first is the role of compression spring which offers resistance to forces moving two components towards each other. Typical applications are car suspension and matters spring. Compression springs typically have their ends end and allowing for easy mounting.

The second common use for helical spring is as a tensioning element. Springs used in this role resists forces moving in two objects away from each other. A couple of common tension spring applications include spring scales and automatic door closers.

\section{Dimension of helical spring}

$\begin{array}{ll}\text { Upper outer diameter } & : 45 \mathrm{~mm} \\ \text { Lower outer diameter } & : 60 \mathrm{~mm} \\ \text { Height of the spring } & : 240 \mathrm{~mm} \\ \text { Diameter of spring wire } & : 6 \mathrm{~mm} \\ \text { Pitch at start } & : 8 \mathrm{~mm} \\ \text { Pitch at end } & : 16 \mathrm{~mm} \\ \text { Pitch at the quarter middle } & : 13 \mathrm{~mm}\end{array}$

II. HARD-DRAWN SPRING STEEL

High-carbon spring steels are the most commonly used of all springs materials. These materials is preferred to others because they are least expensive, readily available, easily worked, and most popular. These materials are not satisfactory for high or low temperatures or for shock or impact loading. Also this is the general purpose spring steels and should only be used where life accuracy and deflection are not too important.

Nominal Chemical Properties

\begin{tabular}{|c|c|c|c|c|}
\hline $\begin{array}{c}\text { Carbon } \\
(\mathrm{C})\end{array}$ & $\begin{array}{c}\text { Manganese } \\
(\mathrm{Mn})\end{array}$ & $\begin{array}{c}\text { Phosphorus } \\
(\mathrm{P})\end{array}$ & $\begin{array}{c}\text { Sulphur } \\
(\mathrm{S})\end{array}$ & $\begin{array}{c}\text { Silicon } \\
(\mathrm{Si})\end{array}$ \\
\hline $0.48-0.85$ & $0.30-1.30$ & $\leq 0.04$ & $\leq 0.05$ & $0.15-0.30$ \\
\hline
\end{tabular}

Table: 1 nominal chemical properties.

Nominal Mechanical Properties

$\begin{array}{ll}\text { Young's Modulus } & : 206000 \mathrm{MPa} . \\ \text { Modulus of Rigidity } & : 85000 \mathrm{MPa} . \\ \text { Density } & : 7800 \mathrm{~kg} / \mathrm{m}^{3} \\ \text { Poissons Ratio } & : 0.33\end{array}$

4.sample caluculation for the helical spring:

Spring index, $C=\frac{D}{d}$

$$
=52.5 / 6=8.75
$$

Wahl's stress factor, $k=\frac{4 C-1}{4 C-4}+\frac{0.615}{C}$

$$
\begin{aligned}
& =\frac{4 \times 8.75-1}{4 \times 8.75-4}+\frac{0.615}{8.75} \\
& k=1.167
\end{aligned}
$$

Maximum shear stress, $\tau=\frac{k \times 8 W D}{\pi d^{3}}$

Deflection of spring, $\delta=\frac{8 W C^{3} n}{G d}$

$$
\begin{aligned}
& =\frac{1.167 \times 8 \times 50 \times 9.81 \times 52.5}{\pi \times 6^{3}} \\
& \tau=354.287 \mathrm{MPa} .
\end{aligned}
$$

$$
\begin{aligned}
& =\frac{8 \times 50 \times 9.81 \times 8.75^{3} \times 16}{87500 \times 6} \\
& \delta=80.115 \mathrm{~mm} .
\end{aligned}
$$


Theoretical Results:

\begin{tabular}{|c|c|c|c|}
\hline S1 No. & Load ' $W$ ' & Maximum Shear Stress ' $\tau$ ' & Deflection ' $\delta$ ' \\
\hline 1 & 50 & 354.287 & 80.115 \\
\hline 2 & 60 & 425.135 & 96.138 \\
\hline 3 & 70 & 495.993 & 112.161 \\
\hline 4 & 80 & 566.851 & 128.184 \\
\hline 5 & 90 & 637.708 & 144.207 \\
\hline
\end{tabular}

Table : 2 stress and deflection of the spring material.

\section{VANADIUM- CHROME STEEL}

Vanadium- Chrome steel is an alloy steel which states that it contains one or more elements other than carbon in sufficient proportion to modify or improve substantially and positively some of its useful properties. They are most popular alloy spring for improved stress, fatigue, long endurance life conditions as compared to high carbon steel materials. Both chromium and vanadium increase the harden ability of steel. Important synergistic effects, not yet fully defined, can also occur when combinations are used in place of single elements. This is best suited for impact and shock loading conditions.

\section{Nominal Chemical Compositions}

\begin{tabular}{|l|l|l|l|l|l|l|}
\hline $\begin{array}{l}\text { Carbon } \\
(\mathrm{C})\end{array}$ & $\begin{array}{l}\text { Manganese } \\
(\mathrm{Mn})\end{array}$ & $\begin{array}{l}\text { Phosphorus } \\
(\mathrm{P})\end{array}$ & $\begin{array}{l}\text { Sulphur } \\
(\mathrm{S})\end{array}$ & $\begin{array}{l}\text { Silicon } \\
(\mathrm{Si})\end{array}$ & $\begin{array}{l}\text { Chromium } \\
(\mathrm{Cr})\end{array}$ & $\begin{array}{l}\text { Others } \\
(\mathrm{Ni}, \mathrm{V} \text { etc. })\end{array}$ \\
\hline $\begin{array}{l}0.48- \\
0.53\end{array}$ & $0.70-0.90$ & $\leq 0.04$ & $\leq 0.04$ & $\begin{array}{l}0.15- \\
0.35\end{array}$ & $0.80-1.10$ & $\leq 0.15$ \\
\hline
\end{tabular}

Table: 3 Nominal chemical compositions

Chromium brings resistance to corrosion and oxidation, high temperature strength and abrasion resistance. Vanadium inhibits grain growth during heat treating while improving toughness of hardened and tempered steels.

\section{Nominal Mechanical Properties}

$\begin{array}{ll}\text { Young's Modulus } & : 207000 \mathrm{MPa} \\ \text { Modulus of Rigidity } & : 87500 \mathrm{MPa} \\ \text { Density } & : 7800 \mathrm{~kg} / \mathrm{m}^{3} \\ \text { Poissons Ratio } & : 0.28\end{array}$

Testing of the spring for various loads:
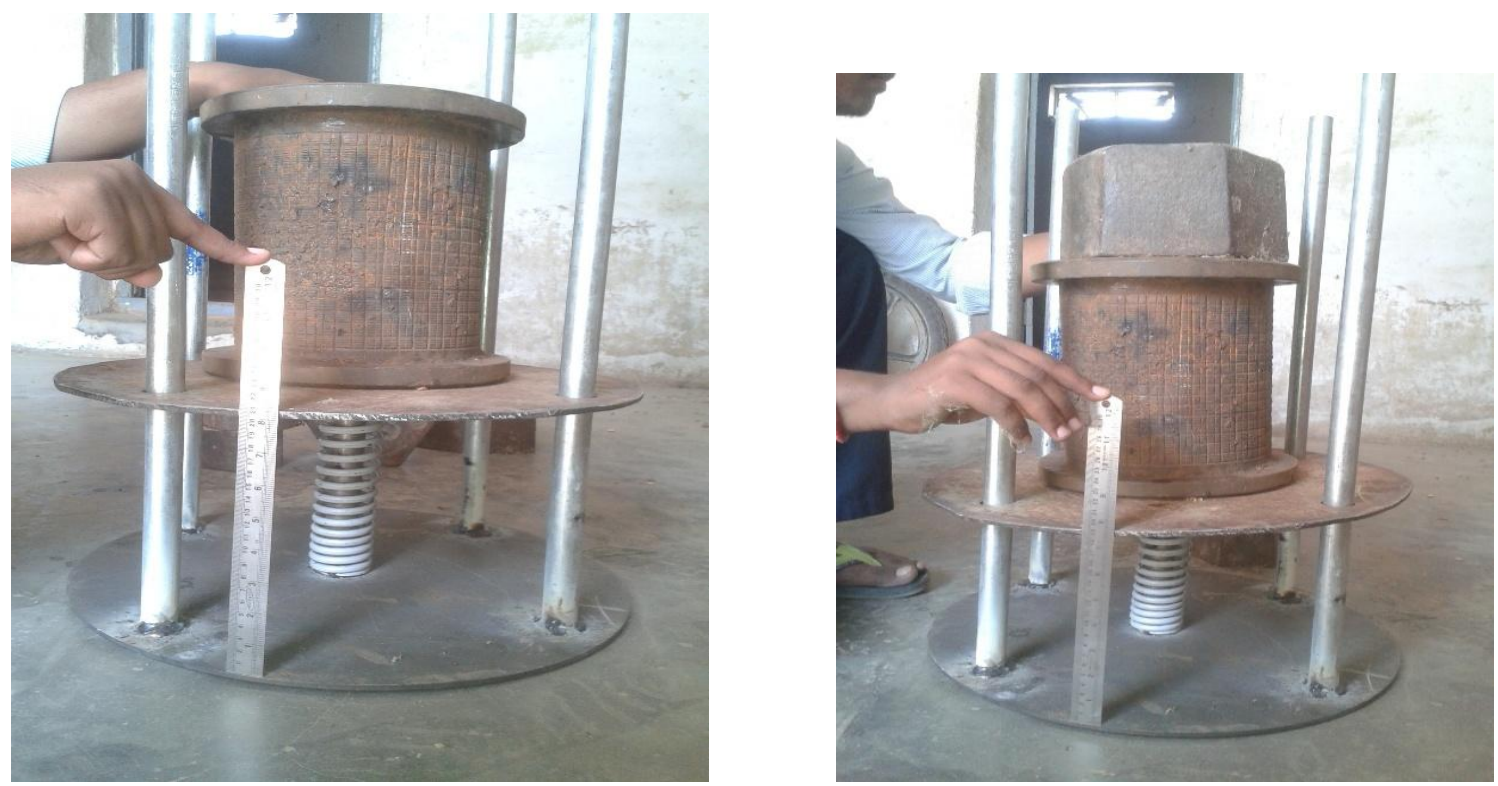

Deflection of the spring for $50 \mathrm{kgs}$

Deflection of the spring for $60 \mathrm{kgs}$ 


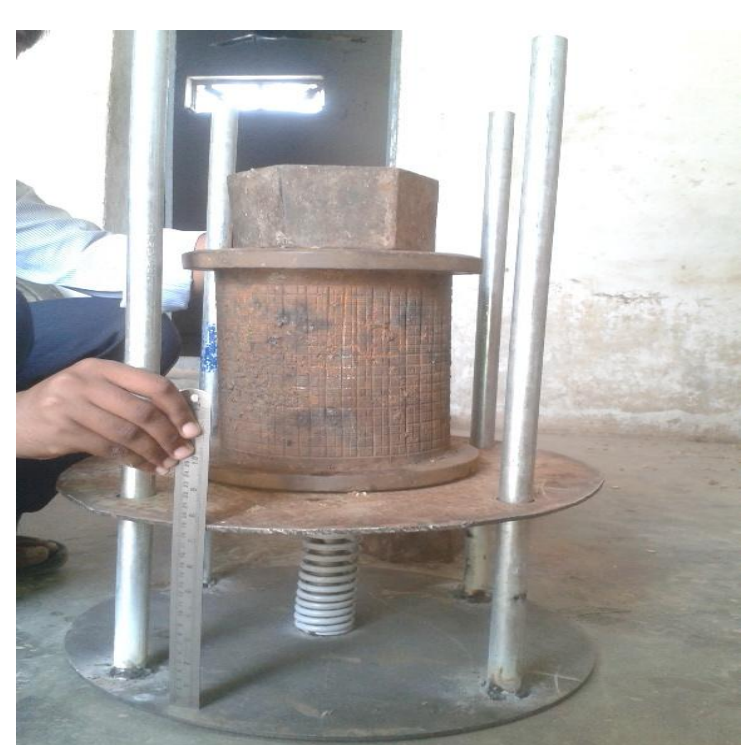

Deflection of the spring for $80 \mathrm{kgs}$

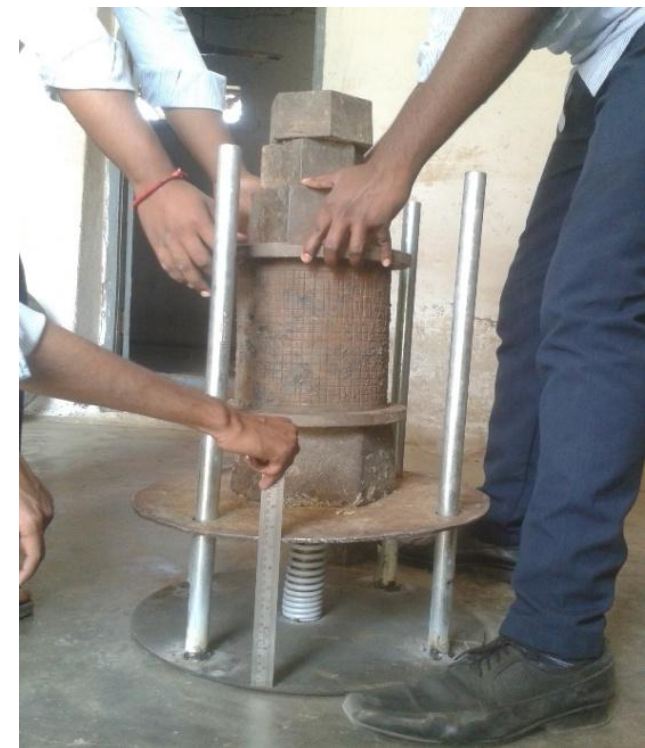

Deflection of the spring for $90 \mathrm{kgs}$

\section{Experimental results:}

\begin{tabular}{|c|c|c|c|}
\hline Sl. No. & Load ' $W$ ' & Maximum Shear Stress ' $\tau$ ' & Deflection ' $\delta$ ' \\
\hline 1 & 50 & 352.932 & 134.733 \\
\hline 2 & 60 & 358.053 & 155.317 \\
\hline 3 & 70 & 446.953 & 158.023 \\
\hline 4 & 80 & 494.609 & 198.307 \\
\hline 5 & 90 & 552.446 & 211.572 \\
\hline
\end{tabular}

Table: 3 The deflctions of the spring under various loads as follows

\section{MODELING OF THE SPRING}

The modeling of the spring is carried out on the pro-e wild fire 5.0

The tool used for the modeling of the spring is helical protrusion. This modeling is based on the variable pitch condition. The spring having variable pitches throughout the spring. The pitch of starting and ending of the spring is small and at middle it is high.

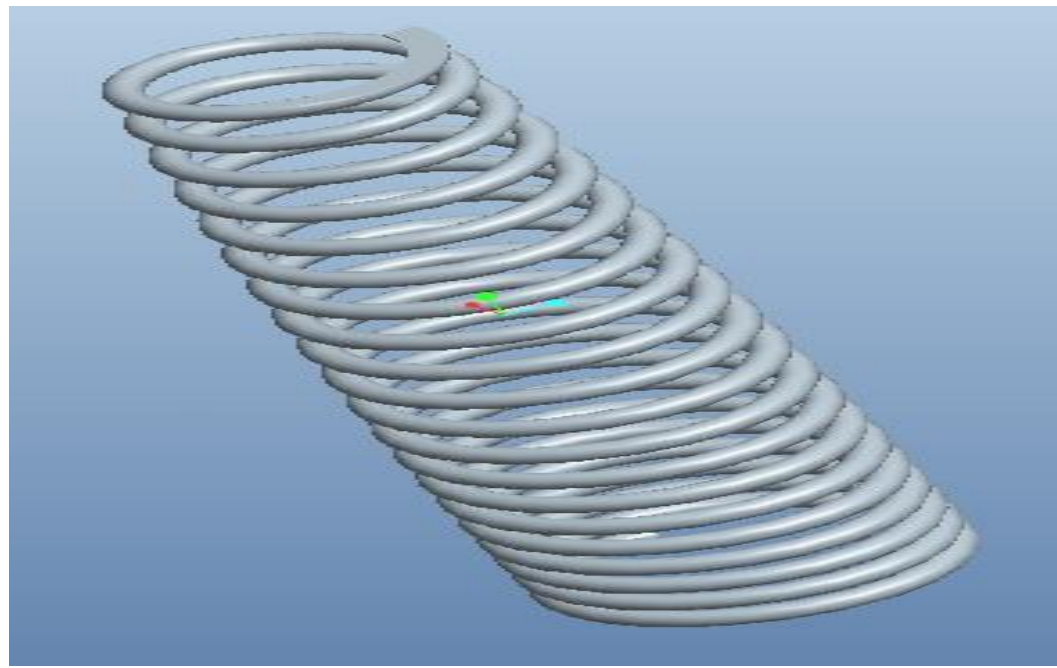

Fig: The Pro-E Model of The Spring

5. analysis of the springs: The analysis is carried out on ansys 14.0

The ansys results for hard drawn steel spring The results are obtained on ansys for spring 

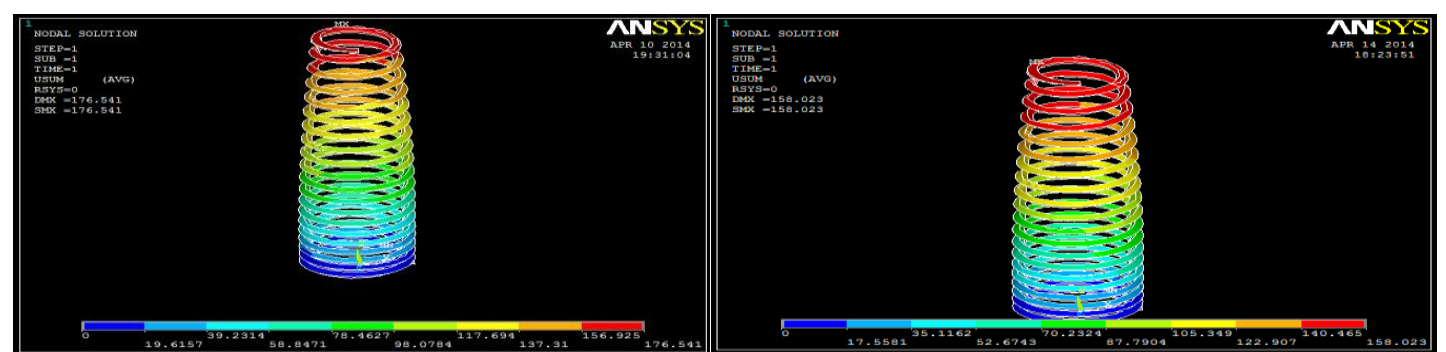

Fig1:Displacement pattern of hard drawn steel spring Fig1:Displacement pattern of hard drawn steel spring

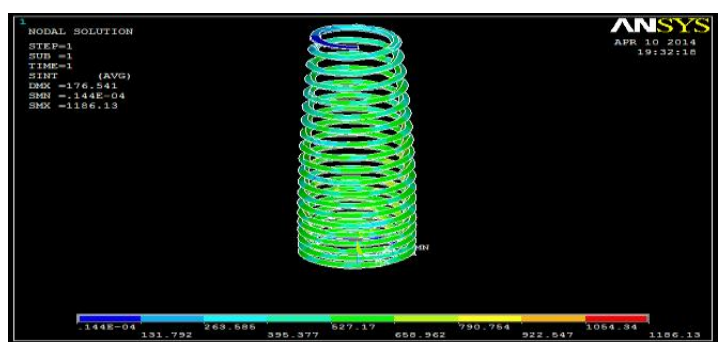

Fig2:stress intencity of spring

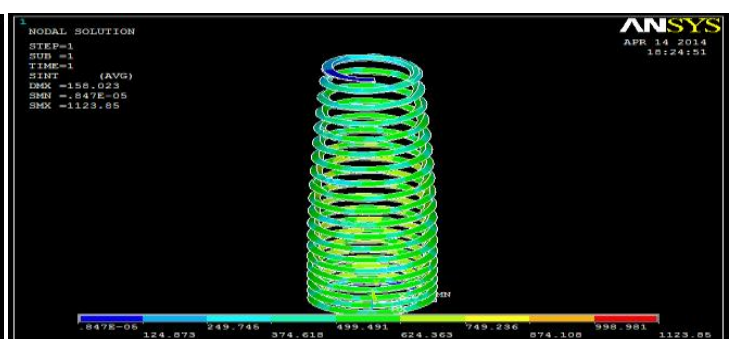

Fig2:stress intencity of spring

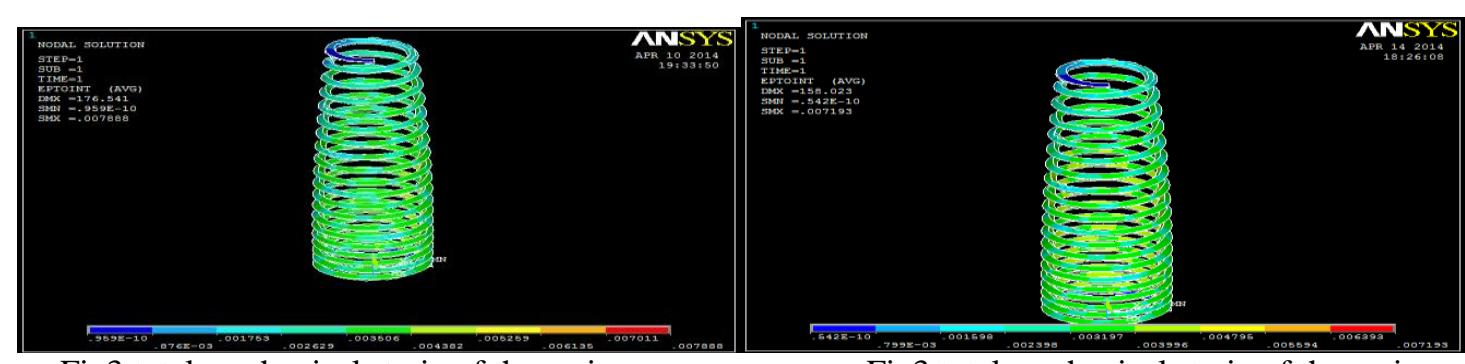

Fig3:total mechanical strain of the spring

Fig3:total mechanical strain of the spring

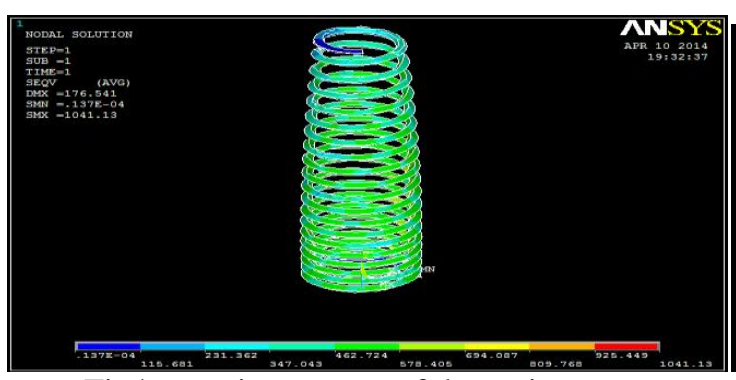

Fig4:vonmisses stress of the spring

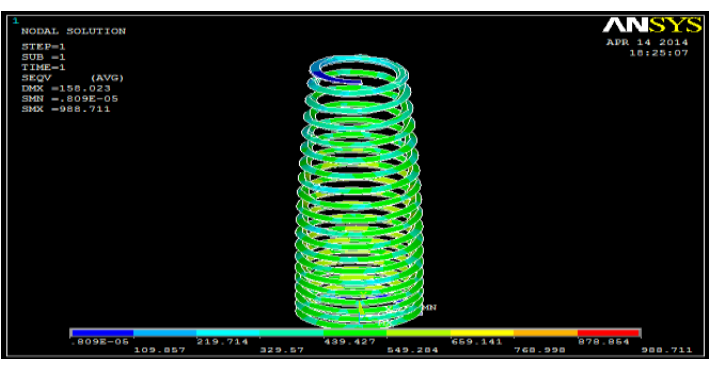

Fig4:vonmisses stress of the spring

Results:

\begin{tabular}{|c|c|c|c|c|c|c|c|}
\hline \multirow[t]{2}{*}{$\begin{array}{r}\text { S1 } \\
\text { No. }\end{array}$} & \multirow{2}{*}{$\begin{array}{l}\text { Load } \\
{ }^{'} W ' \\
(\mathrm{~kg})\end{array}$} & \multicolumn{2}{|c|}{ Theoretical values } & \multicolumn{2}{|c|}{ Experimental values } & \multicolumn{2}{|c|}{ Analytical values } \\
\hline & & $\begin{array}{l}{ }^{'} \delta \text { ' } \\
\text { Stress ' } \tau \text { ' }\end{array}$ & $(\mathrm{mm})$ & $\begin{array}{l}\text { ' } \delta \text { ' } \\
\text { Stress ' } \tau \text { ' }\end{array}$ & $(\mathrm{mm})$ & $\begin{array}{l}{ }^{\prime} \delta \text { ' } \\
\text { Stress ' } \tau \text { ' }\end{array}$ & $(\mathrm{mm})$ \\
\hline 1 & 50 & 354.287 & 80.115 & 352.932 & 134.733 & 365.447 & 144.362 \\
\hline 2 & 60 & 425.135 & 96.138 & 358.053 & 155.317 & 438.733 & 153.852 \\
\hline 3 & 70 & 495.993 & 112.161 & 446.953 & 158.023 & 516.690 & 176.541 \\
\hline 4 & 80 & 566.851 & 128.184 & 494.609 & 198.307 & 595.285 & 204.392 \\
\hline 5 & 90 & 637.708 & 144.207 & 552.446 & 211.572 & 639.787 & 212.855 \\
\hline
\end{tabular}


Table4:The comparision of theoritcal values to the experimental values and analytical values of hard drawn steel

\begin{tabular}{|c|c|l|l|l|l|}
\hline S1. No. & $\begin{array}{c}\text { Load ' } W \text { ' } \\
(\mathrm{kg})\end{array}$ & \multicolumn{2}{|c|}{ HARD-DRAWN SPRING STEEL } & \multicolumn{2}{c|}{ VANADIUM- CHROME STEEL } \\
\cline { 2 - 5 } & & $\begin{array}{l}\text { max Shear Stress ' } \tau \text { ' } \\
\left(\mathrm{N} / \mathrm{mm}^{2}\right)\end{array}$ & $\begin{array}{c}\text { Deflection ' } \delta \text { ' } \\
(\mathrm{mm})\end{array}$ & $\begin{array}{l}\text { max Shear Stress ' } \tau \text { ' } \\
\left(\mathrm{N} / \mathrm{mm}^{2}\right)\end{array}$ & $\begin{array}{c}\text { Deflection ' } \delta \text { ' } \\
(\mathrm{mm})\end{array}$ \\
\hline 1 & 50 & 365.447 & 144.362 & 352.932 & 134.733 \\
\hline 2 & 60 & 438.733 & 153.852 & 358.053 & 155.317 \\
\hline 3 & 70 & 516.690 & 176.541 & 446.953 & 158.023 \\
\hline 4 & 80 & 595.285 & 204.392 & 494.609 & 198.307 \\
\hline 5 & 90 & 639.787 & 212.855 & 552.446 & 211.572 \\
\hline
\end{tabular}

Table5:The comparision of analytical values of existed hard drawn steel to the proposed material of vanadiumchrome steel

\section{CONCLUSIONS}

$>$ The compartive study has been carried out in betwwen the theritical values to the experimental values and the and the analytical values.

$>$ The maximum shear stress of chrome vanadium steel spring has 13-17\% less with compare to hard drawn steel spring.

$>$ The deflction pattern of the chrome vanadium steel spring $10 \%$ less at specified weight with compare to the hard drawn steel spring.

$>$ It is observed that $95 \%$ of the similarity in deflction pattern and $97 \%$ similarity in sher stress pattern between experimenatal values to the analytical values.

$>$ It is observed that $60 \%$ similarity in between theritical values of deflection to the experimental values and $85 \%$ similarity in maximum sher stress of spring.

\section{REFERENCES}

[1] DESIGN OF HELICAL COIL COMPRESSION SPRING” A REVIEW” by P.S.Valsange / International Journal of Engineering Research and Applications, ISSN: 2248-9622.

[2] "STATIC ANALYSIS OF HELICALCOMPRESSIONSPRING USED IN TWOWHEELER HORN" by S.S. Gaikwad, P.S. Kachare, International Journal of Engineering and Advanced Technology (IJEAT) ISSN: 2249 - 8958, Volume-2, Issue-3 February 2013.

[3] INVESTIGATION OF PROBABLE FAILURE POSITION IN HELICAL COMPRESSION SPRINGS USED IN FUEL INJECTION SYSTEM OF DIESEL ENGINES,

[4] IOSR Journal of Mechanical and Civil Engineering (IOSRJMCE) ISSN: 2278-1684 Volume 2, Issue 3 (Sep-Oct. 2012), PP 24-29. 